agreement, both in principle and detail, with those recommended by the present Committee.

There is little necessary connection between the study of the humanities and the teaching of languages; the latter properly falls under the head of a science, and the traditional connection arises from both having formerly been the province of one group of men. Before the days of the conflict of studies, the time devoted to Latin and Greek was far greater than was needed for the languages themselves, and the remainder was well spent on Literæ Humaniores. The present Report deals admirably with the question of the scientific and grammatical study of language; sections 254 to 266 are well worth reading in their entirety; but we are not concerned at the moment with the training of language specialists; we are, however, deeply interested in the problem of transferring to the teacher of English the functions formerly performed by the classics master in connection with the humanities. The first requisite for this transfer is to provide teachers adequately cultured; the next is to ensure the right use by them of the material available.

The Committee, therefore, had to decide what are the right methods of teaching; it also had to consider what modifications in these methods are appropriate to public elementary and preparatory schools, continuation, commercial, and technical schools, teachers' training colleges, and the universities; in addition, it felt constrained to prove that too little importance at present attaches to the study of English in all these institutions. Hence the Report covers so much ground that some search is needed to discover the teaching methods advocated.

A few extracts may, however, give some idea of the Committee's views. In commending recent progress it says :

"Exercises in both descriptive and imaginative writing, as well as practice in verse composition, in letter writing, and in dialogue, are common in the early stages. Many interesting experiments have been tried with a view to encouraging selfexpression. These include debates, improvised dialogues, and dramatic scenes, and ten-minute lectures by pupils, in class as well as in out-of-school hours." "There is a far wider range of reading than formerly. . . Rapid and enjoyable reading is no longer an exceptional thing; the class themselves take more part in the lesson and express their likes and dislikes freely.". . . Not less important than the art of writing is the art of speaking, which includes practice not only in framing questions and answers, but also in reading aloud, recitation, debating, and drama." "A reasonable study of phonetics by the teacher should enable him to give guidance and to correct some of the most common and jarring mistakes of pronunciation." "The rendering of literature by the voice is not a mere matter of mechanical correctness, but is the final result of sympathetic entry into the spirit of the writer, and without it no education in letters can be complete."

The interest in lessons on such lines need never flag; but a note of warning is sounded. Since the reading and writing of English have an intimate and personal touch for the Englishman, they form a perfect medium for a humane education, but there is a possibility that an enthusiast may press this advantage too far and thrust himself unbidden into an inner sanctuary of the adolescent soul. It is significant that the Committee has received warning of this danger from headmasters of public schools, and not from other teachers, for a man who works in boarding-schools is apt to know more of the real boy and his reticences than the master in sa day school. Hesitation on these grounds differs fundamentally from the objections of the conservative teacher whose sense of the ludicrous is stimulated by the thought of his class criticising a great author or acting scenes from a play, or of the disciplinarian who prefers the rigidity of dullness to the apparent disorder of a vividly interested class, or even of the man who feels that literature would be spoiled for the student by being read in school; but the Committee is probably right in holding that the danger is not great, and that in any event the gain is worth the danger.

In fine, to discover a medium of education in the humanities which is applicable to all sorts and conditions of Englishmen has been a vexed problem for many years, and the Committee has made an excellent case for leading us from the Abana and Pharpar of the classics to wash in the Jordan of English in order to secure a healthy and truly national system of education.

\section{Calcium Carbide and the Board of Trade}

\section{What's a WORD WORTH?}

"“ THE guestion is,' said Alice, 'whether you can make words mean so many different things.'

"'The question is,' said Humpty Dumpty, ' which is to be master-that's all." ",

$\mathrm{T}$ is written: "A rose by any other name would 1 smell as sweet"; perhaps, yet there are occasions when a name may be costly to play with. One of these occurred recently, an amount running into thousands of pounds having, it is said, changed hands in the effort to disestablish the meaning of a name. Called upon to interpret the Act, christened by our Legislature the Safeguarding of Industries Act but more appropriately described as an Act for 
"The Sterilisation of Scientific Inquiry, the Retardation of Industry and the Stay of Progress in Education," an Act which penalises all our scientific workers, the lawyers have been disputing over the term Chemical and have practically decided that it has no meaning. They have toyed with the doublet Organic Chemical and their dialectics have landed them in the conclusion that chemists do not in the least know where they are-so they proceed to tell them where they are not. The decisions read like those given in Wonderland, being on strictly "Humpty Dumpty" lines; they are akin to his famous reading of "toves":

"Well, 'toves' are something like badgersthey're something like lizards-and they're something like corkscrews."

Now a wrangle is on over Fine Chemical, a term that has never been defined and is indefinable.

According to the Schedule to the Act, protection is given to "All synthetic organic chemicals ... analytical reagents, all other fine chemicals and chemicals manufactured by fermentation processes."

The Board of Trade, putting its own interpretation upon these words, has produced a very long list of dutiable chemicals; but this is deemed so imperfect that several hundred applications have been lodged to amend it. One of the articles not on the list is Calcium Carbide and an inquiry has been held, at intervals lasting over many weeks, into the legitimacy of the claim that this substance is a synthetic organic chemical, to be ranked in the army of the protected.

An advocate learned in the law but without knowledge of chemistry, sitting unassisted by an expert assessor, after hearing many witnesses for and against, no one of whose testimony, it is obvious, could he well appraise, without attempting to deal with the adjective "synthetic," has pronounced that the carbide is not even an organic chemical.

Given such a tribunal, the issue is obviously a matter of chance; chemists would be equally unable to decide with justice in cases into which purely legal considerations entered. Still, the decision is a serious reflection upon the mental attitude of the chemist--upon his failure to think and speak only in precise terms. Unfortunately the "Ignorance of the Learned "- - Hazlitt's memorable phrase-is always with us.

Calcium carbide, as every motorist and most intelligent people to-day know, gives acetylene as sole gaseous product when water is dropped upon it, the hydrogen of the water being exchanged for the calcium of the acetylide (carbide) and vice versa. The synthesis of acetylene, from carbon and NO. 273 O, VOL. IO9] hydrogen at the temperature of the electric arc, was first effected in 1859 by Berthelot. That the distinguished French ehemist bad no doubt of the organic nature of the compound is clear from the fact that he describes the method in his "Chimie Organique fondée sur la Synthèse" and also in his "Leçons sur les Méthodes générales de Synthèse en Chimie Organique "(1864). Practically speaking, it is the fundamental synthesis of organic chemistry, the foundation upon which the vast series of constructive processes which render the science so remarkable has been developed.

If there be one word in use in chemistry which, after long dispute, has a defined and accepted meaning, it is the word "organic." The dispute began with Wöhler's discovery, in 1828 , that urea-the organic compound which every human being voids daily in considerable quantity-could be made by a purely artificial process: the birth of synthetic organic chemistry is to be dated from that moment; structural chemistry became possible only after Frankland had introduced the conception of valency $\left(\mathrm{I} 85^{2}\right)$. Then system began. The prince of systematists, Kekulé, in $185^{1}$, first defined Organic Chemistry as the Chemistry of the Carbon Compounds. Others followed him. When Schorlemmer, considerably later, suggested as the better definition - The Chemistry of the Hydrocarbons and their Derivatives-he took care to point out that "compounds containing one atom of carbon such as $\mathrm{CO}_{2}$, $\mathrm{COCl}_{2}, \mathrm{CS}_{2}, \mathrm{HCN}$, which are commonly described in the inorganic part, are as much derivatives of marsh gas, $\mathrm{CH}_{4}$, the most simple hydrocarbon, as methyl alcohol and formic acid." In his "Rise and Development of Organic Chemistry," in discussing a series of organic syntheses, he makes special reference to that of acetylene and immediately afterwards remarks: "after this the synthesis of organic compounds made rapid progress."

What does it matter where the chemist may choose to describe a carbon compound, as a matter of convenience and policy, to-day? To put port into a lower instead of into an upper bin does not change the wine to sherry. No legal dialectics can depose a substance from its proper place in the chemist's system.

In fact, the decision of the Board of Trade Referee is an offence against both chemical tradition and our chemical conscience. Appeals, with reference to chemicals, under the Act, if they are to be heard justly, should be submitted to a tribunal of chemists learned in chemical science, not to an arbitrator only learned in the law, whose attitude can but be that of "Humpty Dumpty." H. E. A. 